\title{
KEEFEKTIFAN PEMBELAJARAN BERBASIS PENDIDIKAN KEWIRAUSAHAAN BERBANTUAN BUKU PANDUAN MOTIUATIF DALAM MENINGKATKAN KEMAMPUAN MENULIS GERITA PENDEK
}

\author{
SUDIYATI \\ SMA N 6 Semarang \\ sudi.smansix@gmail.com \\ Pertama Diterima: 06 Mei 2017 Bukti Akhir Diterima: 07 Juni 2016
}

\begin{abstract}
Abstrak
Penelitian berfokus pada pembelajaran berbasis pendidikan kewirausahaan berbantuan buku panduan motivatif. Tujuan penelitian adalah untuk mengetahui keefektifan pembelajaran berbasis pendidikan kewirausahaan berbantuan buku panduan motivatif dalam meningkatkan kemampuan menulis cerita pendek siswa. Penelitian ini merupakan penelitian kuantitatif. Penelitian dilakukan terhadap siswa SMA Negeri 6 Semarang kelas XI. Metode pengumpulan data melalui tes kemampuan menulis cerita pendek. Teknik analisis data menggunakan rumus t-test untuk mengetahui adanya peningkatan hasil sebelum dan sesudah perlakuan. Hasil penelitian menunjukkan bahwa nilai t hitung 6,62 dan pada taraf signifikan 5\% dan $\mathrm{n}=30$ diperoleh $\mathrm{t}$ tabel $=1,68$ yang berarti bahwa $\mathrm{t}$ hitung lebih dari $\mathrm{t}$ tabel sehingga menunjukkan bahwa ha diterima. Dengan demikian pembelajaran menulis cerita pendek berbasis pendidikan kewirausahaan berbantuan buku panduan motivatif efektif dalam mengembangkan kemampuan menulis cerita pendek.
\end{abstract}

Kata Kunci: buku panduan, kemampuan menulis cerpen, kewirausahaan, motivasi

\begin{abstract}
This research focused on entrepreneurship education-based learning within motivation guidebook. Purpose of the research was to determine the effectivity of the entrepreneurship education-based learning within motivation guidebook on students' short story writing skill. This research was a quantitative type of research. It was conducted to students of grade XI in SMA Negeri 6 Semarang. Data collection method was a short story writing test. Data analysis was conducted by t-test formula to determine whether there was an improvement before and after the treatment. Result of the research indicated that value of $t_{\text {count }}$ was 6.62 and on $5 \%$ significance, $n=30, t_{\text {table }}=1.68$. The $t_{\text {count }}$ was higher than $t_{\text {table, }}$, meaning that ha was acceptable. Thus, the learning of entrepreneurship education-based short story writing within motivation guidebook was effective to develop short story writing skill.
\end{abstract}

Keywords: guidebook, short story writing skill, entrepreneurship, motivation 


\section{PENDAHULUAN}

Tuntutan era informasi global menghendaki setiap insan memiliki kemampuan berpikir kritis, kreatif, logis, sistematis selain memiliki karakter terpuji, seperti tanggung jawab, disiplin, rajin, dan produktif (Darmasyah, 2010). Kemampuan yang dimiliki setiap insan merupakan esensi Pendidikan Bahasa dan Sastra Indonesia di sekolah sehingga pembelajaran Bahasa Indonesia sebagaimana yang dituntut dalam kurikulum pendidikan, berperan sangat strategis dalam peningkatan kualitas sumber daya manusia Indonesia.

Guru sebagai pendamping proses pembelajaran tentu saja harus mahir dalam mengidentifikasi masalah dan mencari solusi permasalahan (Chatib, 2011). Salah satu cara mengatasi masalah pembelajaran adalah dengan menggunakan media pembelajaran yang telah disesuaikan dengan masalah yang sedang terjadi dalam proses pembelajaran (kontekstual).

Apresiasi terhadap pembelajaran yang menyenangkan tentu saja diterjemahkan berbeda-beda oleh guru. Sistem kerja yang berlaku adalah mengubah pola pikir peserta didik, agar bertindak ke arah yang lebih positif (Tarigan, 1993). Memutarbalikkan pola pikir peserta didik terhadap mata pelajaran yang dianggap membosankan, tidak menarik, dan sukar terhadap pembelajaran, misalnya pelajaran sastra praktis menulis cerita pendek yang dianggap sukar. Kekesalan peserta didik bertambah besar, saat mereka menemukan kesulitan diberbagai kompetensi. Hasilnya, mereka tidak mau berusaha, pasrah, bahkan menolak pelajaran tersebut. Keadaan yang rentang ini perlu mendapat solusi yang mutakhir dan variatif. Solusi tersebut dapat dihasilkan dari berbagai masalah yang telah dialami para penulis cerpen yang sukses, para ahli pembelajaran yang memiliki pedoman teoretis mengenai proses pembelajaran, guru sebagai pelaku yang selalu mengamati proses pembelajaran menulis cerpen, dan para peserta didik sebagai pelaku pembelajaran (Hanifah, 2010).

Buku panduan motivatif mengandung bentuk media grafis. Pengertian media grafis adalah sarana yang berperan sebagai penyalur pesan dari pengirim pesan kepada penerima pesan. Proses kerja media tersebut mengandalkan simbol-simbol, garis-garis, gambar, maupun titik yang bersifat visual. Media jenis ini hanya mampu ditangkap oleh indera penglihatan (Wena, 2011, hal 116). Buku panduan termasuk dalam kategori satuan lambanglambang bunyi yang berfungsi apabila dibaca oleh peserta didik. Motivasi adalah proses yang memberi semangat, arah, dan kegigihan perilaku. Artinya, perilaku yang memiliki motivasi adalah perilaku yang penuh energi, terarah, dan bertahan lama (Duncan, 2005). 
Serangkaian gambaran terhadap buku panduan motivatif dalam pembelajaran menulis cerita pendek yang berbasis pendidikan kewirausahaan mengindikasi bahwa media ini memiliki beberapa keunggulan. Buku panduan pembelajaran yang sesuaikan dengan isi diharapkan mampu mengurangi beban peserta didik dalam menelaah isi buku panduan (Shancez, 2003) . Hal tersebut mampu terjadi, karena media audio siaga membantu membacakan isi buku panduan tersebut. Bahasa motivatif yang terkandung dalam media pembelajaran merupakan bahasa yang dipilih oleh para responden (Pintrich, 1996). Keungggulan atas penerapan prinsip kewirausahaan juga diindikasikan mampu memberi motivasi untuk optimalisasi pencapaian keberhasilan (Petkova, 2008). Titik keberhasilan dalam proses pembelajaran tesebut adalah peserta didik mampu menulis cerpen dengan baik, menarik, dan berharga jual. Oleh karena itu, rangkaian konsep media pembelajaran dalam bentuk buku dan audio berpadu dengan prinsip kewirausahaan merupakan media yang tepat dalam proses pembelajaran menulis cerita pendek.

\section{METODE PENELITIAN}

Metode yang digunakan dalam penelitian adalah penelitian eksperimen yang bertujuan untuk mengetahui keefektifan pembelajaran bermuatan pendidikan kewirausahaan berbantuan buku panduan motivatif dalam meningkatkan kemampuan menulis cerita pendek.

Populasi dalam penelitian adalah siswa kelas XI SMA Negeri 6 Semarang. Metode pengumpulan data menggunakan instrumen tes kemampuan menulis cerita pendek. Skor menulis cerita pendek peserta didik ditentukan dari unsur-unsur pembengun cerita. Perubahan kearah peningkatan kemampuan atas pembelajaran menggunakan buku panduan motivatif berbantuan audio dalam pembelajaran menulis cerita pendek bermuatan pendidikan kewirausahaan ditentukan berdasarkan hasil sebelum pembelajaran dan setelah pembelajaran menulis cerita pendek. Beberapa aspek penilaian, yaitu tema dan amanat; latar; diksi dan gaya bahasa; sudut pandang pengarang; tokoh dan penokohan; alur, dan keterpaduan unsur pembangun cerita pendek (Pourkalhor, 2013).

Data observasi dalam kegiatan pembelajaran berbantuan buku panduan motivatif yang bermuatan pendidikan kewirausahaan kepada para responden juga perlu dianalisis. Data observasi meliputi reaksi peserta didik setelah menggunakan buku panduan motivatif berisi pendidikan kewirausahaan dan kemampuan peserta didik yang diwujudkan dalam tes menulis cerita pendek. Reaksi peserta didik direalisasikan dalam bentuk catatan-catatan khusus, sedangkan hasil tes direalisasikan dalam bentuk karangan cerita pendek. Identifikasi cerita pendek yang baik diukur menggunakan rincian kriteria cerita pendek yang baik. Tingkat 
keberhasilan pembelajaran menulis cerita pendek tahap pertama dapat diidentifikasi melalui skor yang diperoleh peserta didik. Skor peserta didik mencapai rata-rata 80 menandakan bahwa proses pembelajaran tersebut berhasil dengan baik. Teknik analisis data yang digunakan dalam pengujian hipotesis menggunakan rumus $t$-test untuk mengetahui adanya peningkatan hasil sebelum perlakuan dan sesudah perlakuan.

\section{HASIL PENELITIAN DAN PEMBAHASAN}

Keterampilan peserta didik dalam proses pembelajaran menggunakan buku menulis cerpen yang bermuatan kewirausahaan dikategorikan berhasil. Dua proses yang telah dilaksanakan dalam tes uji coba menulis cerita pendek mampu menuntaskan $76 \%$ dari 30 jumlah peserta didik dengan nilai rerata 80,2. Persentase ini sangat menggembirakan.

Meningkatnya kemampuan keterampilan menulis adalah akibat usaha pembebasan rasa tegang dan tertekan, sehingga peserta didik mampu berekspresi dalam mengolah keterampilan imajinasi. Deskripsi mengenai keefektifan tersebut dideskripsikan dalam rekaman pembelajaran dan hasil aplikasi buku menulis cerpen yang bermuatan kewirausahaan keterampilan menulis cerita pendek.

Kemampuan peserta didik yang diuji dalam 7 (tujuh) aspek nampak dalam proses prapembelajaran dan pascapembelajaran. Tingkatan nilai dan kategori merupakan cerminan yang bersifat semi konkret untuk mengukur kemampuan peserta didik dalam proses menulis cerita pendek. Berdasarkan identifikasi hasil tulisan, perkembangan kemampuan dapat dilihat dalam tabel dan diagram berikut.

Tabel 1 Perkembangan Kemampuan Menulis Cerita Pendek

\begin{tabular}{llrlll}
\hline \multirow{2}{*}{ No } & \multirow{2}{*}{ Kriteria Penilaian } & \multicolumn{2}{c}{ Prapembelajaran } & \multicolumn{2}{c}{ Pascapembelajaran } \\
\cline { 3 - 5 } & & Persen & Kategori & Persen & Kategori \\
\hline 1 & Tema & $58.3 \%$ & Cukup & $82.7 \%$ & Baik \\
\hline 2 & Latar & $55.3 \%$ & Cukup & $73.0 \%$ & Baik \\
\hline 3 & Diksi dan gaya bahasa & $41.0 \%$ & Kurang & $69.7 \%$ & Baik \\
\hline 4 & Sudut pandang & $47.7 \%$ & Kurang & $79.0 \%$ & Baik \\
\hline 5 & Tokoh dan penokohan & $53.3 \%$ & Cukup & $82.8 \%$ & Sangat baik \\
\hline 6 & Alur & $62.8 \%$ & Baik & $82.8 \%$ & Sangat baik \\
\hline 7 & Kepaduan unsur pembangun & $53.0 \%$ & cukup & $83.3 \%$ & Sangat baik \\
\hline
\end{tabular}


Perkembangan yang signifikan pada semua unsur menulis, memperlihatkan keberhasilan dan ketepatan buku menulis cerpen yang bermuatan kewirausahaan dalam pembelajaran menulis cerita pendek. Makna dan suasana yang diciptakan oleh media tersebut mampu melipatgandakan kemampuan menulis peserta didik secara terbimbing. Kemampuan menulis tema meningkat dari angka 58,30\% menjadi $82,70 \%$. Atau berubah dalam kategori baik. Kemampuan menulis latar meningkat dari angka 55,30\% menjadi $73 \%$ atau berubah dalam kategori baik. Kemampuan menulis diksi dan gaya bahasa meningkat dari angka $41 \%$ menjadi $61 \%$ atau berubah dalam kategori baik. Kemampuan menulis sudut pandang pembaca dalam karya cerpen meningkat tajam dari $47,70 \%$ menjadi $79 \%$ atau berubah dalam kategori baik. Kemampuan menulis tokoh meningkat dari angka 53,30\% menjadi $82 \%$ atau berubah dalam kategori sangat baik. Kemampuan menulis alur meningkat dari angka 62, 80\% menjadi $82,8 \%$ atau berubah dalam kategori sangat baik. Kemampuan menulis kepaduan unsur pembangun meningkat pesat, dari angka 53\% menjadi $83,30 \%$ atau berubah dalam kategori sangat baik.

Peningkatan kemampuan tersebut didukung dari kemampuan peserta didik telah banyak meningkat. Berdasarkan tabel berikut, peserta didik yang mengalami peningkatan atau telah lulus (mencapai lebih dari 76) sebagai berikut.

Tabel 2. Tingkat Ketuntasan Keterampilan Menulis Cerita pendek

\begin{tabular}{cccccccc}
\hline & Prapembelajaran & \multicolumn{5}{c}{ Pascapembelajaran } \\
\hline $\begin{array}{c}\text { Tidak } \\
\text { Tuntas }\end{array}$ & Persen & Tuntas & Persen & $\begin{array}{r}\text { Tidak } \\
\text { Tuntas }\end{array}$ & Persen & Tuntas & Persen \\
\hline 28 & $93.3 \%$ & 2 & $6.7 \%$ & 7 & $23.3 \%$ & 23 & $76.7 \%$ \\
\hline
\end{tabular}

Peserta didik yang tidak tuntas dalam menulis cerita pendek dalam tes prapembelajaran sebesar 28 peserta didik, sedangkan yang tuntas hanya sekitar 2 peserta didik. Setelah peserta didik mengalami proses pembelajaran dengan bantuan buku menulis cerpen yang bermuatan kewirausahaan keterampilan menulis cerita pendek, hasil nilai menunjukkan peningkatan ketuntasan peserta didik. Peserta didik yang tuntas atau memiliki nilai lebih dari 75 sebesar 23 peserta didik, sedangkan peserta didik yang tidak tuntas sebanyak 7 peserta didik. Hal tersebut digambarkan dalam grafik peningkatan ketuntasan keterampilan menulis cerita pendek berikut. 


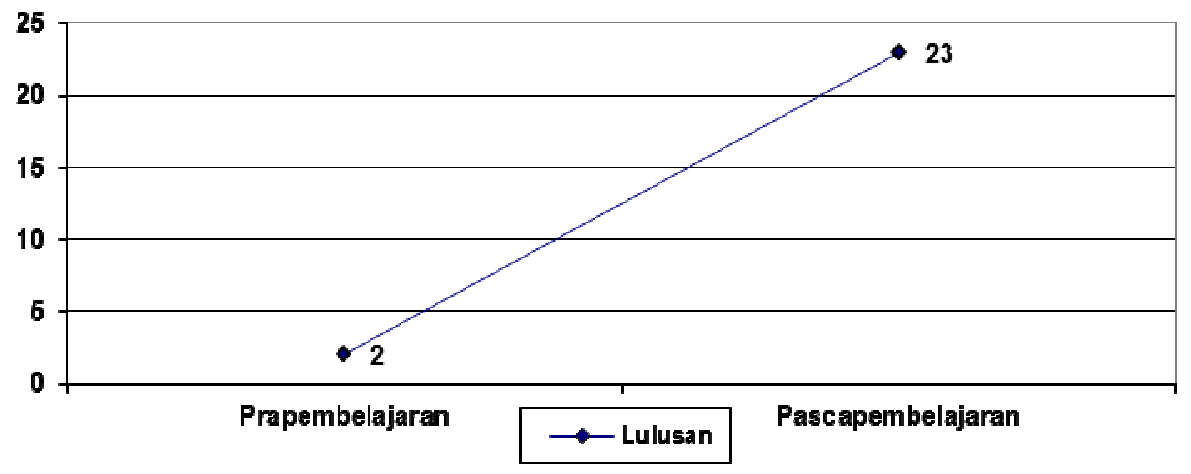

Gambar 4.7 Grafik Tingkat Ketuntasan Keterampilan Menulis Cerita pendek

Dalam penelitian ini, analisis data yang digunakan adalah uji t, yaitu untuk menguji keefektifan buku panduan motivatif berbantuan audio dalam pembelajaran menulis cerita pendek yang berbasis pendidikan kewirausahaan pada siswa kelas XI IPA 1 SMA Negeri 6 Semarang.

Berdasarkan perhitungan uji $t$, diperoleh hasil $t_{\text {hitung }}=6,7$ selanjutnya dikonsultasikan dengan tabel pada taraf siginifikan 5\% dengan $\mathrm{db}=\mathrm{N}-1=30-1=29$ yaitu sebesar 1,68. dengan demikian diperoleh bahwa $t_{\text {hitung }} \geq t_{\text {tab }}$ pada taraf signifikan $5 \%$. Jadi $h_{0}$ yang berbunyi "Buku panduan motivatif yang berbantuan audio yang berbasis pendidikan kewirausahaan tidak efektif dalam pembelajaran menulis cerita pendek" ditolak, yang berarti bahwa $h_{a}$ yang berbunyi "Buku panduan motivatif yang berbantuan audio yang berbasis pendidikan kewirausahaan tidak efektif dalam pembelajaran menulis cerita pendek pada siswa kelas XI IPA 1 SMA Negeri 6 Semarang" diterima

Keefektifan buku menulis cerpen yang bermuatan kewirausahaan dalam proses pembelajaran merupakan prestasi dalam pengembangan media audio yang dipadukan dengan unsur prinsip kewirausahaan. Kegiatan pembelajaran keterampilan menulis cerita pendek Bermuatan Kewirausahaan pada kenyataannya membutuhkan bimbingan yang intensif, untuk menghasilkan karya sastra yang menarik, selaras, dan benar.

Cara pandang hasil pembelajaran berdasarkan aplikasi buku menulis cerpen yang bermuatan kewirausahaan ditimbulkan dari beberapa indikasi, yaitu (1) nuansa prinsip kewirausahaan meningkatkan ketahanan belajar; (2) proses mendengarkan efektif dalam proses pembelajaran materi; (3) materi yang berkesan menimbulkan ingatan jangka lama; (4) mewujudkan suasana humanis dalam proses pembelajaran; dan (5) peran pendampingan guru menyempurnakan fungsi buku menulis cerpen yang bermuatan kewirausahaan. 


\section{PENUTUP}

Hasil penelitian menunjukkan bahwa pembelajaran bermuatan kewirausahaan buku panduan motivatif efektif dalam mengembangkan keterampilan menulis cerpen, peneliti dapat memberikan saran yaitu pembelajaran berbantuan buku panduan motivatif dapat digunakan untuk semua materi, sedangkan untuk penelitian lebih lanjut, buku panduan motivatif bisa dikembangkan dengan berbantuan audio ataupun video.

\section{DAFTAR PUSTAKA}

Arikunto, Suharsimi. (2006). Prosedur Penelitian: Suatu Pendekatan Praktis. Jakarta : Rineka Cipta.

Arsyad, Azhar. (1997). Media Pembelajaran. Jakarta: PT Raja Grafindo Persada.

Chatib, Munif. (2011). Gurunya Manusia. Bandung: Kaira.

Darmasyah. (2010). Strategi Pembelajaran Menyenangkan dengan Humor. Jakarta: PT Bumi Aksara.

Duncan, T. G., \& McKeachie, W. J. (2005). The making of the motivated strategies for learning questionnaire. Educational Psychologist Journal, 40(2): 117-128.

Hanifah, Nanang dan Cucu Sahana. (2010). Konsep Strategi Pembelajaran. Bandung: Rafika Aditama.

Kustadi, Cecep dan Bambang Sutjipto. (2011). Media Pembelajaran Manual dan Digital. Jakarta: Ghalia Indonesia.

Lucia, (2012). Pengembangan Model Pembelajaran Live In dengan Pendekatan Kontekstual untuk Meningkatkan Kemampuan Menulis Cerpen bermuatan Moral Peserta Didik SMA. Tesis:Universitas Negeri Semarang.

Prastowo, Andi. (2012). Panduan Kreatif Membuat Bahan Ajar Inovatif. Yogyakarta: Divapress

Petkova, Antoaneta P. (2008). A Theory of Entrepreneurial Learning from Performance Errors. Int Entrep Manag Journal, Vol.2, 008-0075.

Pintrich, P. R. \& Schunk, D. H. (1996). Motivation In Education: Theory, Research And Applications. Englewood Cliffs: Prentice-Hall Inc.

Pourkalhor, Omid dan Nasibeh Kohan. (2013). Teaching Reading Comprehension Through Short Stories in Advance Classes. Asian Journal Of Social Scienccesand Humanitis. Vol 2 No. 2 pp.52-60 
Shancez, Jose F. F. (2003). "Postmodern Aproaches to The Short Story. Journal of English Student .London: Westpot Connecticut London., Vol. 4, 231-236.

Tarigan, Henry Guntur. (1993). Menulis : Sebagai Suatu Keterampilan Berbahasa. Bandung : Angkasa

Wena, Made. (2011). Stragegi Pembelajaran Inovatif Kontemporer. Jakarta: Bumi Aksara. 